\title{
Research on the whole life cycle of the PPP Project Consulting Business Process Reengineering of Cost Engineering Consultation Company
}

\author{
Xinyan Sun \\ Technical economy and management, Tianjin University of Technology, Tianjin, 300384, China
}

547925874@qq.com

Keywords: PPP project; Demand recognition; Full life cycle; Business process reengineering

\begin{abstract}
Public_-Private-Partnership (PPP) model is widely used in the field of infrastructure and public utilities in China, which provides a "blue ocean" for the business development and enterprise development of engineering cost consulting enterprises. Compared with traditional DBB (Design-Bid-Build) mode, there are differences in accuracy in the content of advisory services and consulting services of PPP projects. Through the analysis of PPP project consulting needs, drawing on business process reengineering technology, the article builds a new process of project cost consulting enterprise to carry out PPP project life cycle consulting business.
\end{abstract}

\section{Introduction}

Public_-Private-Partnership (hereinafter referred to as PPP model) model in China's public utilities supply and infrastructure construction in the ascendant, however, the project cost consulting business in the conduct of PPP business still faces many problems, such as: PPP project consulting Service needs are blurred; PPP project demand for project cost management and PPP consulting business supply between the contradictions; consulting services required for the lack of specialized institutions and professionals; The laws and regulations required to provide advisory services are imperfect [1]. These problems are likely to lead to out-of-control investment in PPP projects, subsidies or charges are extremely high, and it is necessary to carry out the "bottom-up" application research from the perspective of the supply side - to clarify the key elements of the PPP project consulting business China's actual business consulting or transformation of the corresponding consulting business through innovative supply to meet the new needs of the consulting business.

\section{Research on the Present Situation of PPP Mode and Business Process Reengineering}

\section{The development of PPP mode:}

In November 2013, the Third Plenary Session of the Eighteenth Central Committee of the Communist Party of China put forward "to substantially reduce the government's direct allocation of resources" and "encourage social capital to participate in urban infrastructure investment and operation through franchising." Since then, after a long period of brewing and development, PPP model in China's infrastructure construction and public utilities supply areas in full swing [2]. As of March 2017, the Ministry of Finance National PPP integrated information platform for the total investment of 145000 billion yuan investment projects, the number of projects about 12,300.

However, in the face of the new environment of the construction industry, in the face of the new requirements put forward by the PPP model, the services provided by the engineering cost consulting enterprises can't meet the needs of the project. The following problems exist:

(1) PPP project consulting services are not clear: engineering cost consulting firm can't provide effective supply, advisory services tend to procedural, consulting results tend to template, business supply tend to low-end; 
(2) There is a contradiction between PPP project demand for engineering cost consulting and PPP consulting business supply: on the analysis of the Ministry of Finance and the Social Capital Cooperation Center of the storage project, more than half of the return of the project to pay the government fee or feasible, and the cost or cost of the PPP project has a great influence on the general public budget expenditure. To control the cost or cost of the PPP project is the actual demand, However, it is necessary to clearly define that the PPP project advisory services should have the actual capacity and the PPP project cost consulting or investment management consulting services.

In view of the above problems, this paper constructs a new life cycle consulting service for PPP projects by identifying the requirements of PPP project consulting, using business process reengineering theory and based on the whole process cost consulting business of engineering cost consulting enterprise.

\section{Business process reengineering:}

Business Process Reengineering (BPR) is a fundamental rethinking and thorough redesign of traditional business processes, resulting in significant improvements in business (such as cost, quality, etc.), and businesses can so as to adapt to the business environment or new customer demands which is characterized by the 'customer, competition, change' [3]. Business process reengineering is based on the traditional business processes of the enterprise.

The traditional service of the whole process of consulting, its main service object is DBB (Design-Bid-Build, that is, design - bidding - construction) model for engineering contracting and construction of the project construction. That is, the current process of the entire cost of consulting business adapted from the owners were commissioned by the design, construction of the project. Compared with the whole process cost consulting in DBB mode, the cost of PPP project is earlier, the precision is higher, the professional cross is even more, and the life cycle is covered. This study suggests that we can adjust, integrate or streamline the whole process cost consulting business process in the DBB model, and establishment of the PPP project for the whole life cycle consulting business process.

\section{PPP project consultation requirements identification}

Based on BPR project management theory, business process reengineering should first carry out "business needs assessment". This article uses the concept of "customer voice" (VOC) in Total Quality Management (TQM) to collect qualitative materials - customer's or consultant's requirements for PPP project advisory services through semi-structured field interviews. The interviews were conducted in 16 provinces, autonomous regions and municipalities, involving 45 regions, cities or counties, the total number of interviews were 87 , the following table is an excerpt of some representative interviews: 
Table 1 Excerpts of Interviews

\begin{tabular}{|c|c|c|}
\hline Numbering & category & Part of the interview statement excerpt \\
\hline 1 & $\begin{array}{l}\text { Alleviate the financing } \\
\text { pressure of local } \\
\text { financing platform }\end{array}$ & $\begin{array}{l}\text { Before the PPP model, the company's "city investment } \\
\text { debt" is about } 12 \text { billion, about } 2018 \text { years ago to repay, } \\
\text { PPP model is a new way of financing and funding } \\
\text { sources. }\end{array}$ \\
\hline 2 & $\begin{array}{l}\text { Determination of Total } \\
\text { Investment Estimation } \\
\text { of New Project }\end{array}$ & $\begin{array}{l}\text { The PPP project under operation is based on the total } \\
\text { investment estimate of the project, and the estimates are } \\
\text { not allowed, which directly affect the project financing } \\
\text { and the actual implementation, so need to be able to } \\
\text { estimate as much as possible to calculate the consulting } \\
\text { business. }\end{array}$ \\
\hline 3 & $\begin{array}{l}\text { Determination of asset } \\
\text { value of stock item }\end{array}$ & $\begin{array}{l}\text { This project is based on the value of its assets as the } \\
\text { license fee for the transfer fee of the franchise, but the } \\
\text { current value of the asset has not yet been assessed and } \\
\text { needs this advisory service. }\end{array}$ \\
\hline 4 & Project Feasibility Study & $\begin{array}{l}\text { What is the difference between PPP project feasibility } \\
\text { study report and the general feasibility study report, we } \\
\text { need find a consulting firm to prepare a copy for } \\
\text { reference. }\end{array}$ \\
\hline 5 & $\begin{array}{l}\text { Project Economic } \\
\text { Analysis }\end{array}$ & $\begin{array}{l}\text { This project does not necessarily advance, depending on } \\
\text { the economic viability of the project itself, if you do not } \\
\text { make money, it is impossible to have social capital } \\
\text { willing to participate. }\end{array}$ \\
\hline 6 & $\begin{array}{l}\text { Prepare the project } \\
\text { implementation plan }\end{array}$ & \multirow{3}{*}{$\begin{array}{l}\text { We need to consult the unit to assist in the preparation of } \\
\text { a complete project implementation plan and value for } \\
\text { money and financial capacity of the feasibility study } \\
\text { report, so that the project successfully sent to the higher } \\
\text { level financial sector audit. }\end{array}$} \\
\hline 7 & $\begin{array}{l}\text { Project value for money } \\
\text { evaluation }\end{array}$ & \\
\hline 8 & $\begin{array}{l}\text { Demonstration of } \\
\text { financial affordability }\end{array}$ & \\
\hline 9 & $\begin{array}{l}\text { Design Optimization } \\
\text { Based on Value } \\
\text { Engineering }\end{array}$ & \multirow{2}{*}{$\begin{array}{l}\text { For some PPP projects that are initially designed by the } \\
\text { government, the company can provide design } \\
\text { optimization services based on LCC theory or value } \\
\text { engineering principles, and combine the workability } \\
\text { analysis and BIM technology series software to provide } \\
\text { a more realistic design optimization scheme. }\end{array}$} \\
\hline 10 & $\begin{array}{l}\text { Design Optimization } \\
\text { Based on LCC Theory }\end{array}$ & \\
\hline 11 & $\begin{array}{l}\text { Identification and } \\
\text { sharing of project risks }\end{array}$ & $\begin{array}{l}\text { In assisting the government to promote the PPP project, } \\
\text { the company will issue a set of "Project Risk Sharing } \\
\text { List" according to the project situation to assist the } \\
\text { formulation of PPP project contract terms. }\end{array}$ \\
\hline 12 & $\begin{array}{l}\text { Supervision and } \\
\text { Evaluation of Project } \\
\text { Operation and } \\
\text { Maintenance } \\
\text { Performance }\end{array}$ & $\begin{array}{l}\text { How does the performance appraisal index system of } \\
\text { PPP project establish, how to implement, and how to } \\
\text { cooperate with "incentive compatibility" mechanism }\end{array}$ \\
\hline 13 & $\begin{array}{l}\text { According to the project } \\
\text { contract to determine } \\
\text { the transfer plan }\end{array}$ & $\begin{array}{l}\text { PPP project transfer program how to write, how to } \\
\text { conduct performance testing, consulting companies can } \\
\text { help collect information and issue research reports, on } \\
\text { this basis and then modify. }\end{array}$ \\
\hline
\end{tabular}

Through the comprehensive analysis of the above qualitative materials, the logical sequence and the business essence are revealed. The article classifies these logical sequences and business entities 
and forms the core contents of the five consulting services, as shown in Figure 1 below:

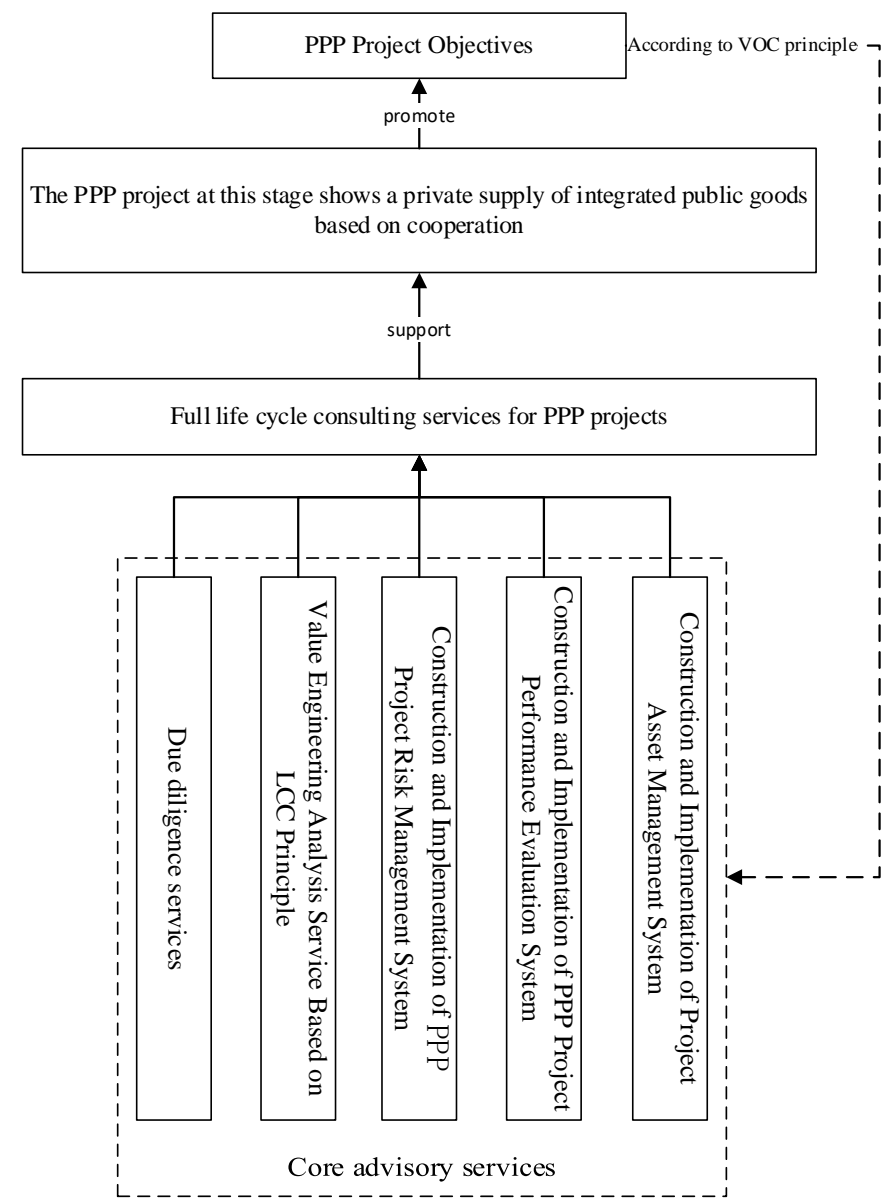

Figure 1 Life-cycle consulting services for PPP projects

Observe the above figure: (1) different PPP projects with different project objectives, at this stage of China's PPP project is integrated through the integration of supply to achieve its "to promote financing" and "efficiency" of the fundamental goal; (2) The PPP project requires a consulting service throughout the life cycle perspective, which satisfies the need for integrated integration tendencies and reduced transaction costs in the context of private supply of public goods.

\section{Research on the Construction of Business Process of Full Life Cycle Consulting}

Through the analysis of the qualitative materials and the stage of the PPP project, the article divides the whole life cycle consultation of the PPP project into the following five modules, and carries out the business process reengineering according to the core service contents of each consulting service module.

\section{Project screening and feasibility analysis module with due diligence as the core}

The module corresponds to the business process for the PPP project identification stage consulting service process. Compared with the traditional process of the whole process of decision-making stage of business decision-making process, the new business process to increase the due diligence, the establishment of the basic project data and database processes. In the new business process, we need to pay attention to PPP project proposal, PPP project output instructions and the initial implementation of the program, PPP project feasibility study report. The due diligence of this stage should be based on the current situation and acquisition methods of PPP project, the value of assets and its ownership, government commitment and project supporting investment, operation mode as the key point. 


\section{Design optimization and implementation of the program module which takes LCC and VE as the core}

The module corresponds to the business process for the PPP project preparation phase consulting service process. Compared to the traditional process of the whole process of consulting, the new business process adds a comprehensive planning based on the Life Cycle Cost principle, the design phase of the business process Optimization and design estimates to determine the process based on the Value Engineering principle. In the new business process, we need to focus on the preliminary design optimization proposal, the initial design of the total budget, PPP project implementation program report, PPP project value for money evaluation and financial capacity demonstration. This stage can use LCC and VE to optimize the preliminary design scheme, optimize the PPP project investment budget, determine the data of the project operation and maintenance, set the reasonable profit rate of the social capital, determine the PPP project return mechanism, determine the cooperation period and establish the performance evaluation system.

\section{Social capital selection and contracting modules with risk management as the core}

This module corresponds to the business process for the PPP project procurement stage consulting service process. Compared with the traditional process of the whole process of consulting the business process, the new business process adds the integration of risk management, according to the tender to confirm the contract negotiations and other processes. In the new business process, we need to pay attention to PPP project tender documents, PPP project contract. This phase can identification risk, assessment risk, curing results of risk sharing of PPP project through the risk management.

Take the performance evaluation system as the core of the implementation of the whole process of supervision module

This module corresponds to the business process for the PPP project implementation phase consulting service process. Compared with the traditional process of the whole process of consulting the business process, the new business process add the establishment of the project company, project construction and construction tasks bidding procurement process. In the new business process, we need to pay attention to the valuation basis for the valuation of the bill of quantities, the construction stage cost management, operation and maintenance phase performance evaluation. This stage can be through the performance evaluation system for the construction of construction, operation and maintenance aspects of performance appraisal.

\section{Project asset management and transfer module with asset management system as the core}

The module corresponds to the business process for the PPP project transfer phase consulting service process. Traditional projects without this process, the PPP project at this stage of the process include: commissioned by the implementation of asset management and transfer work transfer program, asset inventory and assessment, project performance testing, asset disposal and transfer, post-project evaluation. In the above business process, we need to focus on performance testing programs, asset evaluation report. The construction of PPP project asset management system and the actual implementation of asset management work in place is the key application point of asset management system. 


\section{Conclusion}

Based on the theory of business process reengineering, this paper designs a new business process based on the customer demand, the value increment of PPP project and the performance of the PPP project. Based on the analysis of the quality of the PPP project, the whole life cycle consulting business process for the PPP project and the construction of a new business process support environment system, hoping to contribute to the structural cost reform of the project cost consulting firm, and hope to promote China's high quality PPP project to a certain extent Of the implementation of the ground.

\section{References}

[1] Zhou zhengxiang, zhang xiu-fang, zhang ping. Problems and countermeasures of the application of PPP model under the new normal. [J]. China soft science, 2015(9):82-95.

[2] Wang shouqing. The research development and trend of PPP model in China [J]. Journal of engineering management, 2014,06:75-80.

[3] Hammer M,Champy J.Reengineering the Corporation: A Manifesto for Business Revolu-tion[M]. London:Nicholas Brealey Publishing,1993. 